\title{
Customer Participation Rate for Replacement of Old ATM Cards Using BRI GPN ATM Cards
}

\author{
Cahyadi Husadha ${ }^{1}$, Milda Handayani ${ }^{2}$ and Tutiek Yoganingsih ${ }^{3}$ \\ \{cahyadi.husadha@dsn.ubharajaya.ac.id ${ }^{1}$, milda.handayani@ubharajaya.ac.id², \\ tutiek.yoganingsih@dsn.ubharajaya.ac.id $\left.{ }^{3}\right\}$ \\ ${ }^{1}$ Accounting Department, Faculty of Economics, University of Bhayangkara Jakarta Raya, Jl. \\ Perjuangan Raya Bekasi Utara, Kota Bekasi, Jawa Barat 17141, Indonesia. \\ ${ }^{2,3}$ Accounting Department, Faculty of Economics, University of Bhayangkara Jakarta \\ Raya, Jl. Perjuangan Raya Bekasi Utara, Kota Bekasi, Jawa Barat 17141, Indonesia.
}

\begin{abstract}
Bank Indonesia (BI) encourages bank customers to use ATM / Debit cards bearing the National Payment Gate logo (GPN). You do this by exchanging ATM / Debit cards at the nearest bank from 29 July to 3 August 2018. The process of replacing an ATM card with a GPN logo is relatively difficult. At the CS table, customers only need to verify the data and wait around 10 minutes. After waiting, I got the ATM card with the GPN logo on the front of the card. Customers are not charged at all. Executive Director of the Department of Electronification and the National Payment Bank of Bank Indonesia (BI) Pungky Purnomo Wibowo explained; "Merchant discount rates, in our terms it is stated to be $2.6-3 \%$ per transaction fee, now $1 \%$ according to the provisions. We are trying to get people interested in conducting non-cash transactions," then, "If you are a customer of bank A, want transactions in other places that use other bank EDCs, automatically the costs added to the bank. By connecting directly through the GPN, the public will prefer to do non-cash transactions because it is cheaper and safer. " From this study, the results of the discussion that led to the replacement of the old ATM card to the new ATM that had the GPN logo were obtained, were very beneficial and had many benefits. Furthermore, the researchers succeeded in summarizing the results of information and participation of employees and lecturers through social media chat whats the Ubhara Jaya Lecturer and Structural Group app, and also through a brief interview with several Ubhara Jaya employees. In conclusion, that the level of participation in information and replacement services for old ATM cards to new ATM cards bearing the GPN logo was helped by facilitating the campus through mobile BRI service cars which standby on campus according to employee working hours for three days.
\end{abstract}

Keywords: Information, Participation, Benefits and Use, Customer Interest.

\section{Introduction}

Change is happening so fast in line with technological progress. Just call technology correspondence before the revolution which had minimal technology, and more often it was done by meeting and face to face directly. Then, towards the era of revolution 1.0 which took place in the period between 1750-1850. At that time there were massive changes in the fields of agriculture, manufacturing, mining, transportation and technology and had a profound impact on the social, economic and cultural conditions in the world. But correspondence is 
still often done with direct encounters. Correspondence in the form of correspondence using ink pens began to be known and carried out.

The Industrial Revolution 2.0, also known as the Technology Revolution was a rapid phase of industrialization in the late 19th and early 20th centuries. The Industrial Revolution 1.0, which ended in the mid-1800s, was punctuated by a slowdown in macro discovery before the Industrial Revolution 2.0 emerged in 1870. Furthermore, the generation 2.0 industrial revolution was marked by the appearance of electric power plants and combustion chambers. This discovery triggered the emergence of telephones, cars, airplanes, etc. that significantly changed the face of the world. (quoted from; http://otomasi.sv.ugm.ac.id/2018/10/09/sejarahrevolusi-industri-1-0-hingga-4-0/).

With the discovery of the 2.0 industrial revolution, which reportedly can change the face of the world significantly, it also has an impact on correspondence technology in the form of correspondence. And then it began to be known for typewriter technology. From here, it leads us to the next industrial revolution, namely the technology of industrial revolution 3.0.

The emergence of digital technology and the internet marked the advent of the Indonesian Revolution 3.0. The process of industrial revolution if examined from the perspective of British sociologist David Harvey as a process of compression of space and time. Space and time are increasingly compressed. And, this culminated in the phase 3.0 revolution, the digital revolution. Time and space are no longer distant. The second revolution with the presence of cars makes time and distance closer. Revolution 3.0 brings the two together. Therefore, the digital era now carries the side of the present (real time). And in the end, super computer technology emerged which had an impact on the emergence of electronic mail (e-mail), then pagers as a short communication message tool which later gave birth to mobile technology in the form of SMS, and then came to WhatsApp, Line and Instagram technology after going through Facebook twetter and others.

In addition to carrying the present, the 3.0 industrial revolution changes the pattern of relations and communication of contemporary society. Business practices also have to change or not to be swallowed by the times. However, the third industrial revolution also has a side that is worth watching out for. Technology makes factories and industrial machines prefer machines to humans. Moreover, sophisticated machines have the ability to produce more multiples. Consequently, reducing human labor is inevitable. In addition, reproduction also has extraordinary power. In just a matter of hours, many products are produced. Far if done by human power. And this, the world of banking is also participating to compete in choosing and owning the latest systems and technologies that can provide a level of comfort and security for its customers.

\section{Literature Review}

Many experts provide an understanding of the concept of participation. When viewed from the origin of the word, the word participation comes from the English word "participation" which means taking part, participation [1]. Participation means the participation of a person or community group in the development process both in the form of statements and in the form of activities by giving input of thoughts, energy, time, expertise, capital and/or material, and participating in utilizing and enjoying the results of developmen [2]. In essence, participation refers to the awareness of the actors that involved in a system [3]. The notion of participation is expressed by Fasli Djalal and Dedi Supriadi [4], where participation can also mean that decision makers suggest groups or communities to be involved in the form of submitting suggestions and opinions, goods, skills, materials and 
services. Participation can also mean that groups recognize their own problems, examine their choices, make decisions, and solve their problems. According to Sundariningrum in Sugiyah [5] classify participation into 2 (two) based on the way they are involved, namely: a) Direct Participation. Participation occurs when individuals display certain activities in the process of participation. This participation occurs when everyone can submit a view, discuss the subject matter, submit an objection to the wishes of others or to his statement; b) Indirect participation. Participation that occurs when an individual delegates his participation rights.

The form of participation according to Effendi was quoted by Siti Irene Astuti D [6], divided into: a) Vertical Participation. Vertical participation occurs in the form of certain conditions the community is involved or takes part in a program of another party, in a relationship where the community is a subordinate, follower, or client status; b) Horizontal participation. Horizontal participation, the community has an initiative where each member or community group participates horizontally with each other.

According to Belkin [7] information needs is a condition of one's knowledge of a particular situation or topic that is considered inadequate to deal with a situation. While Kuhlthau argues that information needs arise because of a knowledge gap in someone with the information needs needed. So that it can be concluded that information needs arise when someone gets into a problem so they need information that can provide a solution to the problem at hand.

According to Sulistyo-Basuki [7] someone's effort to find the information needed will lead to behavior, whose behavior is called information seeking behavior. To clarify the boundaries of the study relating to users of information systems, Wilson presents several definitions as quoted by Pendit, namely: a) Information behavior (information behavior) which is the overall human behavior related to sources and channels of information, including active search and information behavior. passively; b) Information discovery behavior (information seeking behavior) is an effort to find with a specific purpose as a result of the need to meet certain goals. In this case, someone might interact with a literary information system (newspaper, library) or computer based for example (www); c) Information seeking behavior (information searching behavior) is behavior at the micro level, in the form of a search behavior that is shown by someone when interacting with information systems. This behavior consists of various forms of interaction with the system both at the level of interaction with the computer such as the use of the mouse or the act of clicking a link, as well as intellectual and mental levels, such as boolean use or the decision to choose the most relevant books among a series of books on a library shelf d) The behavior of information use (information user behavior) consists of physical and mental actions carried out by someone when someone combines the information he found with the basic knowledge that he had before.

Information at the present time is very easy to reach. The passage of time must be followed by the continued emergence of information in the world. Information flows are increasingly unstoppable with the internet. Whenever and wherever anyone can get and disseminate information. Various possibilities arise for information that is spread in the community. It can happen because of marketing, sharing, existence, and other reasons. Of the many information available, one must be able to determine which information must be taken or abandoned. This must be done so as not to absorb information that is not true. Therefore, there is a need for someone's perception of the quality of information on the internet, this is an important element for evaluating that information. In his book entitled "Management Information Systems" McLeod and Schell [8] mention there are 4 dimensions needed to be able to add value to an information, namely Relevance, Accuracy, Actual and Completeness. 
Many studies related to the quality of information online. According to Cheung et. al [8], indicators of the quality of information consist of, relevance, timeliness, accuracy, and completeness.

Usability Information is defined as the extent to which readers understand the information received is valuable so that it can help them make better purchasing decisions [7]. Use of Information is an important determinant of Information Adoption. According to Zheng, Youn, and Kincaid [8] 55\% of readers of online reviews look for comments from authors to be used as benefits and bring this information into consideration when making purchasing decisions.

Understanding banks according to Law No. 7 of 1992 [9] concerning banking as amended by Law No. 10 of 1998 [10] where "the Bank is a business entity that collects funds from the community in the form of deposits and distributes them to the community in order to improve the standard of living of many people." According to the opinion expressed by Kasmir [10], Banks can simply be interpreted by financial institutions whose main activities are to collect funds from the public and redistribute the funds to the public and provide other bank services. While the notion of banking itself is everything that concerns the bank, including institutions, business activities, and the process of carrying out activities [11].

Accoording to Abdul Rahman Shalih dan Muhbid Abdul Wahab [12], Interest is a tendency to give attention and act to people, activities or situations that are objects of interest with accompanied feelings of pleasure. In other words there is an effort (to approach, know, master and relate) from the subject that is done with a feeling of pleasure, there is an attraction of the object. Abu Ahmadi stated that, interest means the attention, interest and attention in general is considered the same / there is no difference. Indeed, both are almost the same and in practice are always holding each other together. if someone who is directed at an object actually begins with an interest in that matter. interest is the attitude of the soul of a person including the three functions of his soul (cognition, konasi, emotion), which is directed at a thing and in the relationship the strongest feeling element. Attention is the activity of the soul that is directed to something specific object. In the symptoms of attention, these three functions also exist, but the element of thought is the strongest influence. Between interest and attention is always related to practice. What attracts interest can cause attention and what causes our attention to a certain thing to be accompanied by interest. From his book Abu Ahmadi "General Psychology" which is used as a reference indicator in this study. The following is an explanation of the three indicators that are used as references for the formation of customer interests, namely as follows: a) Cognition (recognition symptoms): The activity or process of acquiring knowledge (including awareness, feeling) or business recognizing something through one's own experience The recognition symptoms in the outline are divided into two, namely through the senses and through reason; b) Emotions (feeling symptoms): a tendency to have distinctive feelings when dealing with certain objects in their environment. (Uswah Wardiana); c) Konasi (Willingness symptom): is one of the functions of human mental life, can be interpreted as psychological activity that contains active effort and is related to the implementation of a goal. A goal is the end point of a movement that leads to a direction [13].

Quite a lot of factors that influence the emergence of interest in something, which can be broadly grouped into two, namely those originating from within the individual concerned (eg weight, age, gender, experience, feeling capable, personality), and originating from outside the family environment, school environment and community environment. While interest according to Crow and Crow in his book Abdul Rahman Saleh argues there are three factors that influence the emergence of interest, namely: a) Encouragement from within the individual, for example the urge to eat, curiosity; b) Social motives, can be a factor that 
arouses interest in doing a certain activity; c) Emotional factors, interests have a close relationship with emotions [11].

\section{Method}

The background of this research is the place where the researcher conducts research, and the phenomena that occur in the subject with social and cultural characters in explaining the background of the study. The place for this research is located at Bhayangkara University, Jakarta Raya, Bekasi Campus. The subjects in this study were lecturers and employees of Bhayangkara University, Greater Jakarta, Bekasi Campus who were still actively working. The population and sample in this study were taken randomly, because the Bhayangkara Jakarta Raya University of Bekasi Campus has a uniform bank account that was appointed separately through the MOU of the Jakarta Campus Bhayangkara Raya Jakarta in the study of Lecturers and Employees who need to be examined. This research is generally carried out with qualitative academic methods. That is a method that tries to find the subject matter and elaboration based on references from several literatures such as journals and other scientific works, which are accompanied by several expert opinions that can be accounted for. The method of collecting data itself is done through direct observation, and library research. Library research is conducted by examining books, journals, and other sources related to the issues of Information, Participation, Benefits and Use, BRI Customer Interest.

The survey is one of the scientific methods that is still quite new. This research developed from the twentieth century. Survey research is seen as one branch of scientific research in social sciences. Its procedures and methods have been developed primarily by psychologists, sociologists, economists, political scientists, and statistics. Survey research is one method of research that generally examines large populations using population samples that aim to make descriptions, generalizations, or predictions about opinions, behaviors, and characteristics that exist in the population. In this study, researchers used a population sample at a higher education institution called Bhayangkara University, Greater Jakarta, Bekasi Campus, which aims to make descriptions, generalizations, or predictions about opinions, behaviors, and characteristics that exist in the population. And this is certainly related to the level of customer participation in the framework of replacing old ATM cards with the use of BRI GPN ATM cards. Therefore, the main material in this study is to use a sample in the form of a purposive sampling technique.

One consideration in choosing a research problem is the availability of data sources. Quantitative research is more explanation (explaining, completing), because it is to learn about the people (object society), while qualitative research is more understanding (phoneme) of phonemes or social symptoms, because it is to learn about the people (people as subjects). The accuracy of selecting and determining the type of data source will determine the wealth of data obtained, the types of data sources especially the nature of qualitative research can be classified as follows: 1) Resources, In quantitative research these data sources are called "Respondents", namely people who give "Response" or responses towards what is requested or determined by the researcher. Whereas in qualitative research, the resource person is very important, not a respondent, but also as the owner of information; 2) Events or Activities, Data or information can also be obtained through observation of events or activities related to research problems. From these events or events, researchers can find out the process of how things happen more definitely because they witness themselves firsthand. By observing an event or activity, researchers can cross check verbal information given by the subject under study; 3) Place or location, place or location related to the target or research problem is also 
one type of data source. Information about the condition of the location of the event or activity carried out can be extracted through the source of the location of the event or the activity carried out can be excavated through the source of the location, whether it is the place or place or environment; and 4) Documents or Archives, Documents are written material or objects related to a particular event or activity. He can be a recording or written document such as a data base archive of letters recording images of relics related to an event.

The techniques in collecting data are as follows: 1) Observation. This observation was carried out to obtain data on the level of customer participation in the framework of replacing old ATM cards with the use of BRI GPN ATM cards, case studies at Bhayangkara University, Greater Jakarta, Bekasi Campus. This observation was carried out by direct observation of the patterns and models of participation of lecturers and employees in the context of replacing old ATM cards with BRI GPN ATM cards; 2) Documentation Study. Documentation study is a study to look for data on things or variables in the form of notes, reports, and important information held by the relevant agencies, regarding Information, Participation, Benefits and Use, Customer Interest. With this technique, it is expected to obtain a theory or concept that has to do with Information, Participation, Benefits and Use, Customer Interest; 3) Interview. Interview is a method or method used to get answers from respondents by unilaterally questioning. Interviews are conducted to obtain data relating to Information, Participation, Benefits and Use, Customer Interest. This interview is aimed at lecturers, employees, and financial planners of Bhayangkara University, Greater Jakarta, Bekasi Campus.

\section{Results And Discussion}

\section{a. Research Result}

Bhayangkara University, Greater Jakarta (Ubhara Jaya) as one of the Private Universities under the guidance of the Brata Bhakti Foundation as its organizing body, is obliged to realize national education goals with its Vision and Mission to support the success of the tasks of the Indonesian National Police in particular and development of quality of life and countries in general.

\section{b. BI and OJK Agree to Migrate to a Fastened Berchip ATM Card}

JAKARTA - Bank Indonesia is sure to advance the deadline for implementing 100\% chip technology on ATM / Debit and credit cards. The migration implemented by banks was also emphasized that BI did not need to wait until December 31, 2021, such as the roadmap for chip technology specification standards on payment instruments. Head of BI Payment System Policy Department Onny Widjanarko in Jakarta on Thursday (3/23) said that BI had evaluated the case of ATM / Debit card skimming that had befallen customers of PT Bank Rakyat Indonesia Persero Tbk in the past two weeks. Data tapping can be done because the ATM / Debit cards of BRI customers who are victims are still using magnetic tape, not chips. "As is known, we have the National Standard of Indonesian Chip Card Specification (NSICCS) implementation for example 2019 must be $30 \%$, then 2021 must be $100 \%$. Now we want to accelerate". However, BI is still reviewing the changes in the right deadline for implementing $100 \%$ ATM / Debit cards with chip technology. Referring to Bank Indonesia Circular Number $17 / 52$ / DKSP, in the NSICCS plan, the Central Bank requires banks to fulfill a minimum of $30 \%$ of outstanding ATM / Debit cards already using the chip at the end of 2018. 


\section{c. Benefits of GPN for the Community}

Executive Director of the Department of Electronification and the National Payment Bank of Bank Indonesia (BI) Pungky Purnomo Wibowo explained; "Merchant discount rates, in our terms it is stated to be $2.6-3 \%$ per transaction fee, now $1 \%$ according to the provisions. We are trying to get people interested in conducting non-cash transactions," then, "If you are a customer of bank A, want transactions in other places that use other bank EDCs, automatically the costs added to the bank. By connecting directly through the GPN, the public will prefer to do non-cash transactions because it is cheaper and safer. " Previously, the community was still difficult if they wanted to transact with an ATM card or bank A debit on bank B's EDC machine. Because indeed some bank systems were not connected to each other. In addition, fees are charged if the cross-bank transaction is also quite large. BI also mentions that the GPN can reduce the monthly administration fees in banks, transfer fees and balance check fees. This is because the entire payment system is connected and causes the costs incurred by the organizer to be easier. For example, at present Mandiri ATM cash withdrawals with other banks using a shared ATM network are charged Rp 7,500, check the balance of Rp 4,000 then online transfer fees Rp 6,500. If connected, the system will be easier and more efficient.

\section{d. BRI Customers Are Required to Change ATM Cards}

JAKARTA, (PR) .- BRI customers, ATM card holders were surprised by the SMS broadcast from BRI that asked their customers to replace their ATM cards. The replacement was allegedly a series of efforts to secure BRI customers from skimming crime that occurred some time ago. "Dear, BRI Customer, for trx security, your ATM card will be deactivated. Immediately change your card at the nearest BRI Branch Office (Free), Contact Info BRI 14017." Thus the contents of the SMS.BRI's Corporate Secretary, Bambang Tribaroto, who was contacted by "PR", Saturday March 24, 2018 gave a brief response about it. "In the context of Bank BRI's preventive efforts to secure customer funds and the process of replacing cards for customer cards suspected of being skimming, we ask the willingness of customers who have received short messages (SMS) from BRI Bank to the nearest BRI Bank branch office to make a replacement the card is free of charge, "said Bambang.

\section{e. Although Not Receiving SMS Notifications, BRI Customers Must Still Change ATM Cards}

JAKARTA, KOMPAS.com - PT Bank Rakyat Indonesia (Persero) Tbk sent a short message (SMS) to a number of customers indicated to make transactions at the location of the ATM that was skimming. Crime using the skimming method is done by stealing customer data and funds on a debit card using a skimmer installed at an ATM machine. When receiving an SMS notification, the customer is required to make a replacement card at the nearest BRI branch office. Card replacement is done today, Saturday (03/24/2018), and Sunday (03/25/2018). Then, what about customers who do not receive SMS notifications regarding card replacement? Are they required to replace the card too? Also read: BRI Customers Start Receiving SMS, ATM Cards Cannot Be Used by Corporate Secretary BRI Bambang Tribaroto explained, SMS is not sent to all customers. The customer who receives the notification SMS is preferred to make a card replacement. Tips for safe transactions from BI. (Bank Indonesia) Customers who do not receive SMS can make a replacement card later today and tomorrow. 
However, all BRI customers must replace the card into a chip technology card. "(SMS notifications) are not sent to all customers. Only to customers who are indicated as having skimming. (Today and tomorrow's card replacement) are prioritized which are indicated to be affected by skimming," Bambang told Kompas.com via a short message. Also read: Deactivation of BRI ATM Cards for Customers Indicated Skimming Affected The card replacement process is carried out without any charge. Bambang explained, notification of notifications continued through SMS blasts, BRI ATM screens and BRI social media accounts. "Socialization is also carried out through BRI employees who have been actively notifying customers since 2 days ago," Bambang explained.

\section{f. Here's how to get a GPN logo card}

The way to get the GPN Logo Card is very easy, namely by visiting the nearest BRI service car to exchange it, or the community can come directly to the banking branch that is used and ask to replace the old card with the GPN logo card.

\section{Discussion}

Departing from the description above, such as; BI and OJK Agree to Migrate to Accelerated Berchip ATM Cards, then information about the benefits of GPN for the public, BRI Customers who are required to replace their old ATM Cards even if they do not receive SMS notifications, come to ways to get an ATM card with a GPN logo. Then the results of the discussion that led to the replacement of the old ATM card to the new ATM that has GPN trading is very beneficial and has many benefits. Apart from that, the researchers managed to summarize the results of information and employees participation and lecturers through whats app social chat, Ubhara Jaya's Lecturer and Structural Group like conversations in fig. 1.

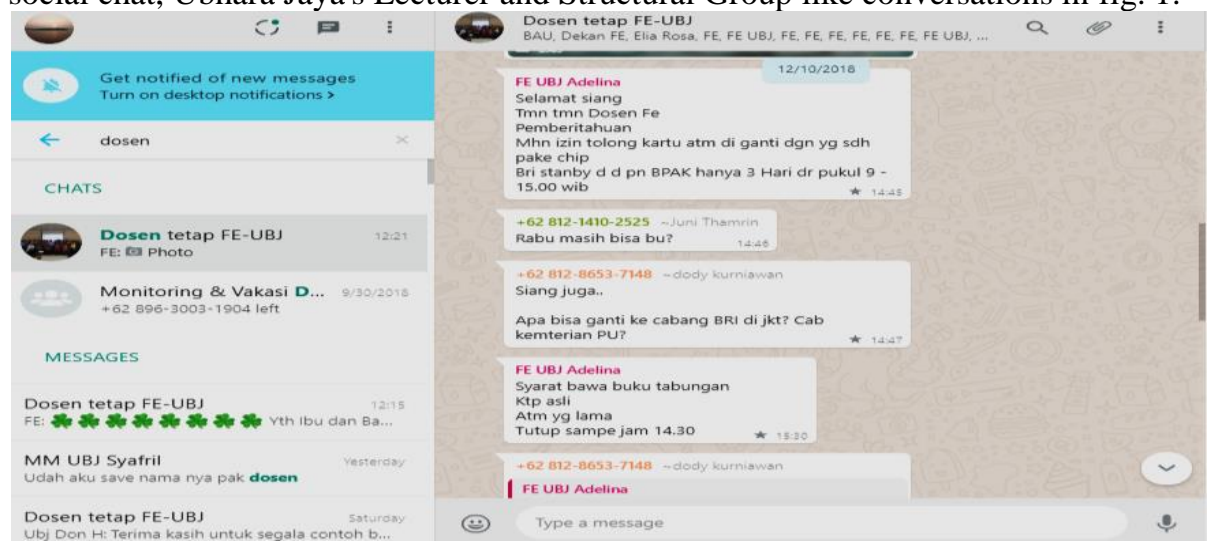




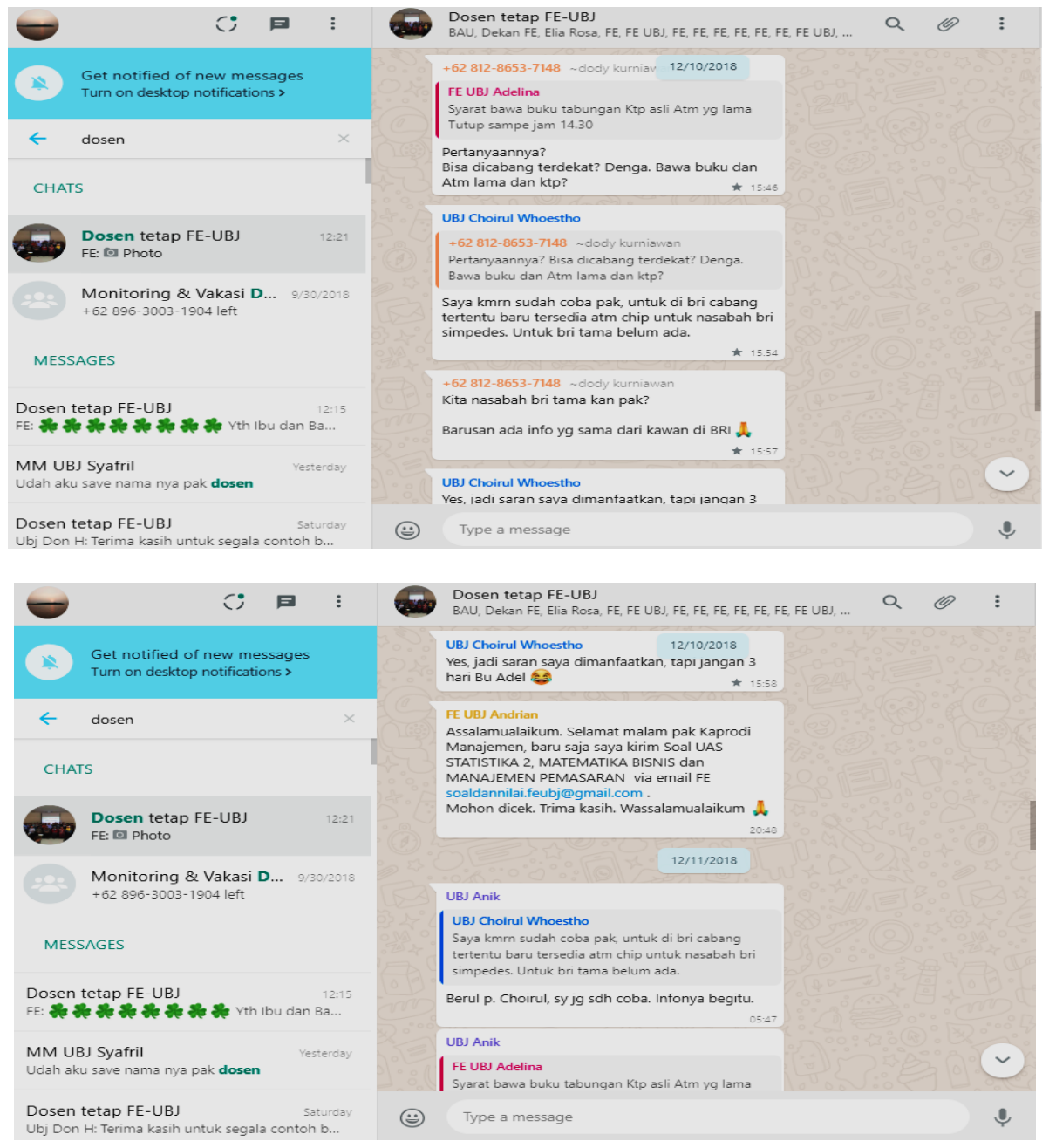

Fig.1. Information and Participation of Lecturers and Structural Ubhara Jaya in the FE Lecturer Group FE about replacing old ATM cards with new ATM cards bearing the GPN $\log 0$

Apart from the image data above, the researcher managed to retrieve information and participation through a brief interview with several Ubhara Jaya employees which concluded that the participation rate for information and service for replacing old ATM cards with new ATM cards bearing the GPN logo was facilitated by bringing mobile BRI service cars that standby on campus according to employee work hours. And this turned out to be responded to by the number of employees who came to the BRI car around per day reaching 30 people per day on the basis of interviews with car officers going around. While the time for visiting BRI cars starts from 08.00 to 15.00 , for 3 days. 


\section{Conclusion}

The level of customer participation in replacing old ATM cards with the use of BRI GPN ATM cards at Universiatas Bhayangkara, Greater Jakarta (Ubhara Jaya), with lecturer and employee case studies, obtained positive results, as evidenced by the participation of lecturers and employees on WhatsApp group media and visits into BRI mobile cars that reach the maximum target of the BRI bank, which is 20 cards per day. As for those who came to the car around BRI as many as 30 people.

\section{References}

[1] Murti, "Validitas dan Reliabilitas Pengukuran," Matrikulasi Progr. Stud. Doktoral, 2011.

[2] I. Sumaryadi, N, "Efektivitas Implementasi Kebijakan Otonomi Daerah," Citra Utama, 2005. .

[3] F. Firdaus, "Evaluasi Proyek Pembangunan Sosial Pada Kelompok Masyarakat Kawasan Hutan Mbeliling, Kab. Manggarai Barat, NTT," J. Ilmu Sos. Mamangan, vol. 5, no. 1, pp. 13-22, 2016.

[4] P. Widoyoko, "Peranan Sertifikasi guru dalam meningkatkan mutu pendidikan," Semin. Nas. Peningkatan Mutu Pendidik. Melalui Sertifikasi Guru di Univ. Muhammadiyah Purworejo, 2008.

[5] I. Mangunatmadja, R. W. Sundariningrum, H. D. Pusponegoro, and E. Windiastuti, "Intracranial hemorrhage in hemorrhagic disease of the newborn," Paediatr. Indones., 2016.

[6] S. I. A. Dwiningrum, "Artikel 6 In Decentraliziting," in seminar internasional di Bali, 2011.

[7] Widiyastuti, "Perbandingan Teori Pelaku Pencarian Informasi Menurut Ellis, Wilson dan Kuhlthau," Inf. Sains, vol. 3, no. 2, pp. 51-64, 2016.

[8] A. Rachmadhani and P. Soenarno, "Dan Dampaknya Pada Adopsi Informasi (Studi pada Masyarakat Pengikut Akun Twitter Resmi iKaskus),” vol. 25, no. 1, pp. 1-8, 2015.

[9] Bank Indonesia, "UU Republik Indonesia No. 7 Tahun 1992 Tentang Perbankan," Undang. NOMOR 10 TAHUN 1998 tentang Perbank., 1998.

[10] Bank Indonesia, "Undang-Undang Nomor 10 Tahun 1998 Tentang Perbankan," Undang. No. 10 Tahun 1998 tentang Perbank., 1998.

[11] A. H. Romdhoni, M. Tho'in, and A. Wahyudi, "Sistem Ekonomi Perbankan Berlandaskan Bunga (Analisis Perdebatan Bunga Bank Termasuk Riba Atau Tidak)," J. Akunt. dan Pajak, vol. 13, no. 01, pp. 22-27, 2012.

[12] Abdul Rahman Shaleh dan Abdul Muhbib Wahab, Psikologi Suatu Pengantar Dalam Perspektif Islam. 2004.

[13] H. Hasbullah, "Lingkungan Pendidikan Islam Dalam Al-Quran dan Hadist," Tarbawi J. Keilmuan Manaj. Pendidik., 2018. 